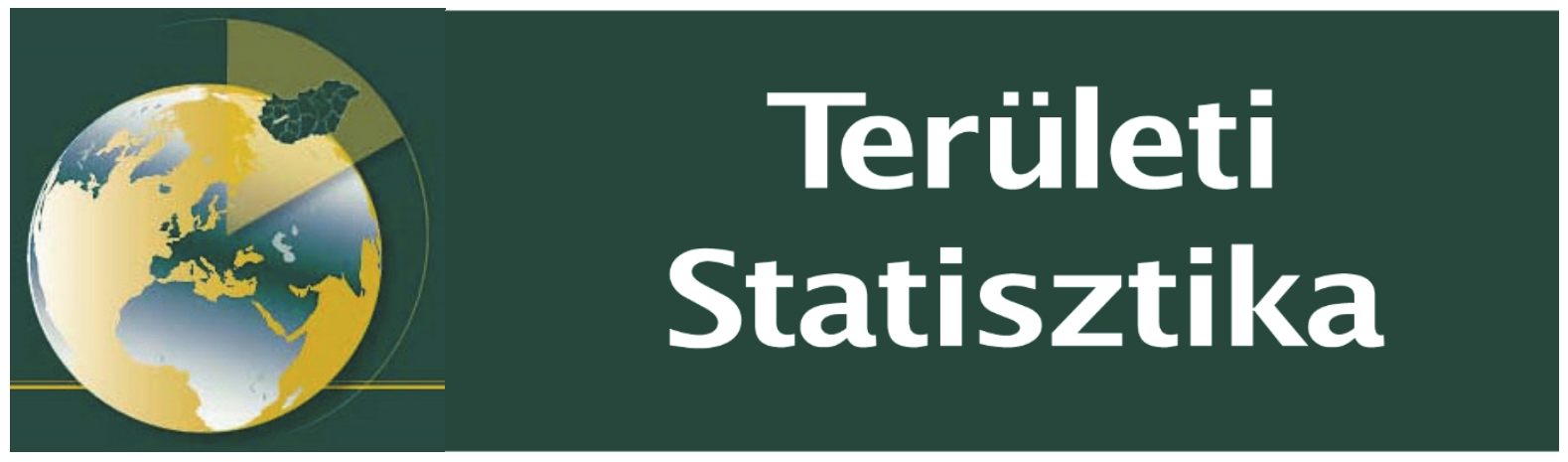

Közzététel: 2020. május12.

A tanulmány címe:

Szerzők:

A smart planning szerepe a fenntartható városfejlesztésben

Szalmáné Csete Mária - Buzási Attila

https://doi.org/10.15196/TS600304

Az alábbi feltételek érvényesek minden, a Központi Statisztikai Hivatal (a továbbiakban: KSH) Területi Statisztika c. folyóiratában (a továbbiakban: Folyóirat) megjelenó tanulmányra. Felhasználó a tanulmány, vagy annak részei felhasználásával egyidejüleg tudomásul veszi a jelen dokumentumban foglalt felhasználási feltételeket, és azokat magára nézve kötelezönek fogadja el. Tudomásul veszi, hogy a jelen feltételek megszegéséböl eredó valamennyi kárért felelösséggel tartozik.

1) A jogszabályi tartalom kivételével a tanulmányok a szerzői jogról szóló 1999. évi LXXVI. törvény (Szjt.) szerint szerzői műnek minősülnek. A szerzői jog jogosultja a KSH.

2) A KSH földrajzi és időbeli korlátozás nélküli, nem kizárólagos, nem átadható, térítésmentes felhasználási jogot biztosít a Felhasználó részére a tanulmány vonatkozásában.

3) A felhasználási jog keretében a Felhasználó jogosult a tanulmány:

a) oktatási és kutatási célú felhasználására (nyilvánosságra hozatalára és továbbítására a

4. pontban foglalt kivétellel) a Folyóirat és a szerző(k) feltüntetésével;

b) tartalmáról összefoglaló készítésére az írott és az elektronikus médiában a Folyóirat

és a szerző(k) feltüntetésével;

c) részletének idézésére - az átvevő mű jellege és célja által indokolt terjedelemben és az eredetihez híven - a forrás, valamint az ott megjelölt szerző $(\mathrm{k})$ megnevezésével.

4) A Felhasználó nem jogosult a tanulmány továbbértékesítésére, haszonszerzési célú felhasználására. Ez a korlátozás nem érinti a tanulmány felhasználásával előállított, de az Szjt. szerint önálló szerzői műnek minősülő mű ilyen célú felhasználását.

5) A tanulmány átdolgozása, újra publikálása tilos.

6) A 3. a)-c.) pontban foglaltak alapján a Folyóiratot és a szerző(ke)t az alábbiak szerint kell feltüntetni:

„Forrás: Területi Statisztika c. folyóirat 60. évfolyam 3. számában megjelent, Szalmáné Csete Mária - Buzási Attila által írt, A smart planning szerepe a fenntartható városfejlesztésben c. tanulmány”

7) A Folyóiratban megjelenő tanulmányok kutatói véleményeket tükröznek, amelyek nem esnek szükségképpen egybe a $\mathrm{KSH}$, vagy a szerzők által képviselt intézmények hivatalos álláspontjával. 


\section{A smart planning szerepe a fenntartható városfejlesztésben}

\section{The role of smart planning in sustainable urban development}

Szalmáné Csete, Mária

Budapesti Műszaki és

Gazdaságtudományi Egyetem

E-mail: csete@eik.bme.hu

Buzási, Attila

Budapesti Múszaki és Gazdaságtudományi Egyetem E-mail: buzasi@eik.bme.hu

Kulcsszavak: smart city (okos város), scorecard módszer,

smart planning, fenntartható városfejlesztés
Jelen tanulmány arra keres választ, hogy városi szinten a digitalizáció korában a fenntarthatóság felé való átmenethez hozzájárulhat-e egy smart city koncepció, s ha igen, akkor vajon milyen módon? A szerzők javaslatot tesznek az ún. smart planning módszer alkalmazására és egy scorecard alapú indikátorrendszer kidolgozására, melyek hozzájárulhatnak a helyi fejlesztési elképzelések fenntarthatóság, klímatudatosság és okosság (smart) szempontjából történő értékeléséhez, iránymutatásul szolgálva a helyi érintettek számára. A kidolgozott indikátorrendszer a városgazdálkodás, -üzemeltetés számára lehetôvé teszi a monitoringfolyamatok hatékonyságának folyamatos fejlesztését, valamint a piaci alapú városfejlesztési beavatkozások ex ante értékelését is. A szerzők esettanulmánnyal vizsgálják a kialakított módszertan és a smart planning értékelés alkalmazhatóságát egy megyei jogú város esetében. $\mathrm{Az}$ ismertetett értékelési rendszer olyan eszközt jelenthet a hazai önkormányzatok számára, mely elősegítheti a helyi sajátosságoknak leginkább megfelelő, költség- és erőforrás-hatékony piaci eszközök azonosítását annak érdekében, hogy a települések fejlesztési céljaihoz legpontosabban illeszkedő és optimális megoldásokat válasszanak ki a smart és a fenntartható városfejlesztés gyakorlati megvalósításához.

In this paper, we sought to answer the question of whether a smart city concept can contribute to the transition towards sustainability at the city level in the age of digitalization, and if so, how. We propose the use of the developed smart planning method and the development of a scorecard-based indicator system that may contribute to the evaluation of the sustainable, 
climate-conscious and smart nature of local development ideas by guiding local decision makers and other stakeholders. Due to this indicator system, the continuous efficiency improvement of monitoring processes can be realized for the city management and operation, as well as the ex-ante evaluation of market-based urban development projects. A pilot study was conducted at a city of county rank in order to examine the feasibility of the developed indicator system and smart planning method. The described evaluation system may be a useful tool for local governments for identifying the most cost-effective and resource-efficient market solutions considering regional characteristics,

Keywords: to select the most appropriate and optimal smart city, solutions according to the development scorecard method, objectives of the municipality fostering the smart planning, practical implementation of smart and sustainable urban development sustainable urban development.

Beküldve: 2019. november 20.

Elfogadva: 2020. február 11.

\section{Bevezetés}

A városi területek a nemzetközi kutatásokban, illetve a gyakorlati fejlesztések esetén is fókuszpontba kerültek, az elemzendő rendszer komplexitásával, illetve a városokban élők számának rendületlen gyarapodásával összefüggésben. Hiába a gyakran évtizedes témák, sokszor az egységesen elfogadott definíciók hiánya és az ezzel kapcsolatos értelmezési heterogenitás az egyik legfőbb gátja a problémák hatékony megoldásának. E megállapítások a kompakt, a smart ${ }^{1}$ és a fenntartható városok témakörében különösen igazak. Jelen elemzés egyik célja, hogy feltárja a kapcsolatot az említett három várostípus között, amelyek esetében természetes kapcsolatok is felismerhetők. Az 1. ábra a kutatási munkafolyamat legfontosabb állomásait és egyben jelen tanulmány felépítését mutatja be.

${ }^{1}$ Tanulmányunkban a smart city és az okos város, valamint a további smart kategóriák és magyar megfelelőik egymás szinonimái.

Területi Statisztika, 2020, 60(3): 370-390; DOI: 10.15196/TS600304 
A kutatási munkafolyamat bemutatása

Presentation of the research process workflow

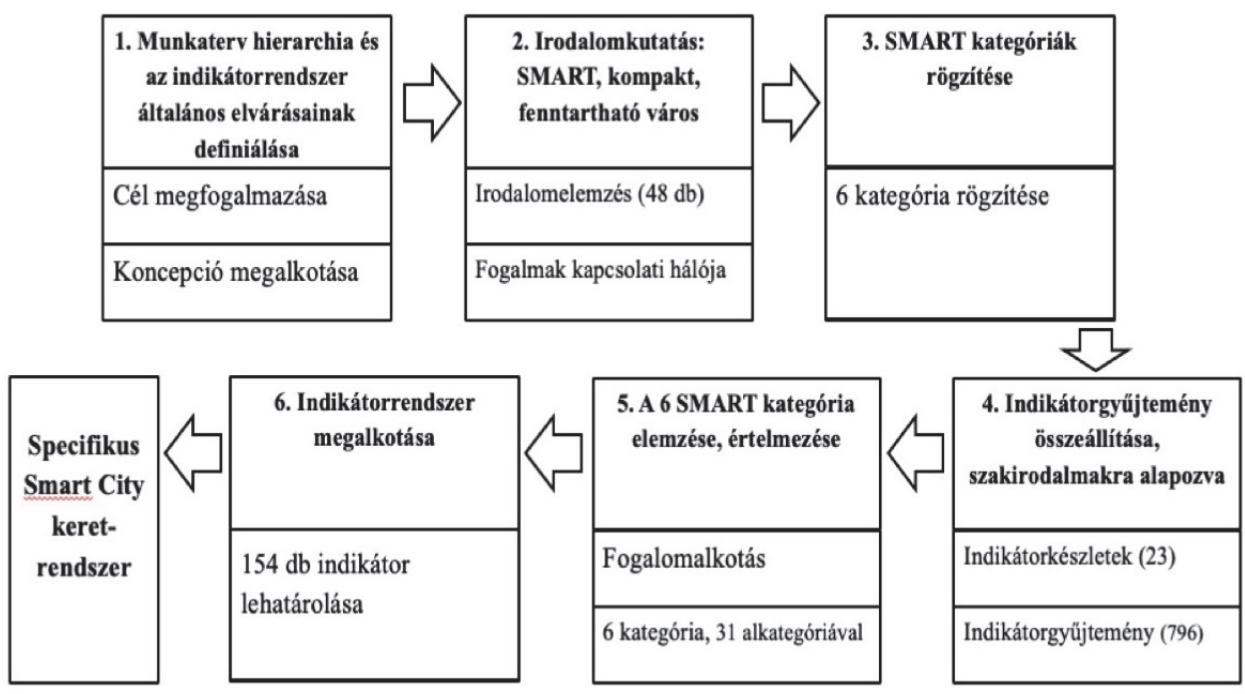

A kapcsolatok feltárása azonban első körben az alkalmazott fogalmak tisztázását igényli, mely után feltárhatók az összefüggések, valamint az az összetett és szerteágazó kapcsolatrendszer, amelynek tisztázása nélkül a kutatás végcélja, azaz a smart városokra alkalmazható indikátorrendszer sem állítható össze. Az így kialakított értékelési keretrendszer segítségével az ún. smart planning módszertan is kidolgozhatóvá válik. A kutatás első felében a városokkal kapcsolatos kihívásokat, illetve a nemzetközi szabályozási és fejlesztési környezetet világítjuk át, majd a különböző fogalmak megértését segítő kapcsolati ábrán áttekintjük a kompakt, a smart és a fenntartható városok definícióját. Az irodalomkutatás eredményeit összegző fejezetet a smart kategóriák rögzitése, vagyis a feldolgozott szakirodalmi bázis szintézise olyan fogalmi meghatározásokkal követi, melyek illeszkednek a kurrens városfejlesztési trendekhez és gyakorlatban is alkalmazhatónak tủnnek. Az egyes smart kategóriák meghatározását azok indikátorokkal való feltöltése jelenti, és segítségükkel megvalósíthatóvá válik az ún. smart planning folyamata, ami a vállalati lehetőségeket a városok fejlesztési céljaival olyan köztes szereplőn keresztül köti össze, amely képes értelmezni és összehangolni a vállalati, az önkormányzati szektor igényeit, valamint erősségeit. A smart planning eszköze, illetve folyamata lehetôvé teszi a smart és a fenntartható városfejlesztési lehetőségek azonosítását, továbbá azok hatékonyságának meghatározását a mindenkori fejlesztési tervek, illetve a tervezett beruházások figyelembevételével. A tanulmányt összefoglaló következtetésekkel és szakmai javaslatokkal, jövőbeni kutatási irányokkal és gyakorlati alkalmazhatósági lehetőségekkel zárjuk. 


\section{Szakirodalmi áttekintés}

A fenntarthatóság gondolata és érvényre juttatása kiemelten fontos a városi területeken az egyre növekvő népesség és gazdasági jelentőség, valamint az ezekkel párhuzamosan fokozódó erőforrás-felhasználás szempontjából. Az ENSZ legújabb, 2018. évi (Bocquier 2018) jelentése szerint a Föld lakosságának több mint fele városokban él, és a tanulmány szerint 2050 -re a városi lakosság aránya világszerte eléri a $68 \%$-ot. A városi népesség arányának eloszlása nem egyenletes, és szignifikáns különbségek mutathatók ki a fejlődő és a fejlett világ urbanizációs fokát tekintve. Megállapítható továbbá, hogy társadalmi szempontból a jövőben a fejlődő világ városiasodása döntő szerepet játszik, vagyis szegények százmillióinak helyzete változik meg drasztikusan.

Az elmúlt két-, háromszáz évben Észak-Amerikában, illetve Európa számos országában az urbanizációs folyamatok lezajlottak, vagyis a városok korábban tapasztalt intenzív növekedése megtorpant, egyes esetekben meg is állt. Ezekkel a folyamatokkal párhuzamosan a fejlődő világ nagyvárosai éppen egy növekedési ciklus kellős közepén tartanak, mely alapvető infrastrukturális és kormányzati defektusok okán súlyos terheket ró az érintett országok gazdasági és társadalmi stabilitására. Mivel utóbbi területek jellemzően a fejlődő világhoz tartoznak, melynek gazdasági, szociális és környezeti tulajdonságai előre vetítik a városnövekedéssel kapcsolatos jövőbeli és már most is jelentkezô kihívásokat. A fejlett világ központjai mind-mind olyan metropoliszok (New York, Tokió, London), amelyek nem az ipari termelésben, hanem a pénzügyi szolgáltatásokban érnek/értek el kimagasló eredményeket (Sassen 2005). Ezzel ellentétben, a fejlődő világ nagyvárosai közül sok a specializált ipari ágazatainak „,köszönheti” kiemelkedő növekedését. A városalakító tényezők ilyen mértékủ differenciálódása a városok fejlődését kiegyenlítetlenül befolyásolja. A mai értelemben vett fejlett városok a nyersanyaglelőhelyek, a szállítási útvonalak, valamint a termelési lehetőségek által előnyösnek itélt helyeken jönnek létre, a többiek viszont lemaradnak.

A folyamatosan romló körülmények miatt a XX. század elejétől megjelentek azok a településtervezési és városfejlesztési irányzatok, amelyek az ökológiai alapelvek megvalósításában látták a megoldást a felmerült problémákra. Az elsőnek tekintett olyan dokumentum, amelyben deklaráltan megjelent a „fenntartható" város, a Local Agenda 21 (LA 21) volt. Az akcióprogramot az ENSZ 1992. évi Rio de Janeiróban tartott, Környezet és Fejlődés címú konferenciáján alkották meg, ahol a fô dokumentum, az Agenda 21 részeként, a 28. fejezetben jelenik meg a fenntarthatóság helyi programja. E dokumentum szerint a városoknak kötelességük olyan fejlódési programot kialakítaniuk, amely figyelembe veszi a jelen és a jövő generációk gazdasági, társadalmi és környezeti problémáit, illetve azokra mindhárom dimenzió esetében hosszú távon is fenntartható és egyben hatékony megoldást javasol.

A XXI. század egyik legnagyobb kihívása a városok fenntarthatóvá tétele, melyet napjaink környezeti, társadalmi és gazdasági folyamatainak alakulása csak tovább nehezít. A városok komplex rendszerek, ezért az innovatív megoldások az ipar, a

Területi Statisztika, 2020, 60(3): 370-390; DOI: 10.15196/TS600304 
közlekedés, a kommunikációs technológiák, a gazdasági szerkezetváltás, a társadalmi kohézió és az érintett felek közötti párbeszéd erôsitése érdekében elengedhetetlenek (Lindenau-Böhler-Baedeker 2014, Soma et al. 2018). E komplex rendszerek ,átalakulása" megköveteli a XXI. századi technológiák használatát, melyek bátran építhetnek az urbanisztika tudománya által meghatározott fogalmakra, köztük a kompakt városszerkezetre (Tappert et al. 2018). A smart technológiák használata a fenntartható városfejlesztés területén mérföldkőnek is tekinthető, mivel ezen műszaki megoldásokat alapvetően optimalizálási feladatok érdekében vezették be, amelyek a városi teruleteken megalapozzák az erőforrásokkal való felelős és hosszú távon is fenntartható gazdálkodást (Verrest-Pfeffer 2018, Joss et al. 2019).

A fenntartható és a smart városok definíciójának hasonlóságára mutatnak rá Lombardi és szerzőtársai (2012), amikor felvetik azokat a rokon kifejezéseket, amelyeket gyakran kevernek a smart city fogalmával, úgymint intelligens és digitális város, melyek - véleményük szerint - az okos városok egy részét képezik, és nem ekvivalens fogalmak. Ez az elkülönítés is mutatja, hogy sok esetben keverednek az első látásra rokon értelmú fogalmak. Ezek a városok információs-kommunikációs technológia (IKT-) infrastruktúrájára, a humán tőke fontosságára és a fó gazdasági hajtóerőkre helyezik a hangsúlyt, szemben az emlitett szerzők által is alkalmazott felbontással, melynek részei a gazdaság, a közlekedés, a környezet, a társadalmi, a jólléti és a kormányzási dimenziók. Ezen felbontás jelenik meg a legtöbb munkában, azonban hasonlóan a fenntartható városok definícióihoz, értelmezésük erôsen heterogén (Caragliu et al. 2011, Dameri 2012). Ezen klasszikus dimenziók mentén utóbbi szerzők a smart városok tekintetében kiemelték a regionális versenyképesség, az erőforrások optimális felhasználásának, az életminőségnek és a társadalom széles köre bevonásának kérdéskörét. A smart gazdaság részletes definíciója azt olyan iparágakkal jellemzi, ahol az IKT-megoldások előtérbe kerülnek. A társadalmi aspektust a városlakók képzettségével, valamint a döntéshozatali folyamatban megjelenő szerepükkel jellemzik (Lombardi et al. 2012, Batty 2013).

Összefoglalva, az említett szerzők által alkotott smart city definíció az IKTlehetőségek kiaknázására épít és azt emeli ki. Angelidou (2014) az okos városok térbeli kérdéseivel foglalkozik, részben a meglévő irodalmak összefoglalásával, részben azok összehasonlításával. Véleménye szerint - hasonlóan az előzőkben ismertetett definícióhoz - a smart városok esetében az IKT-k használata áll a középpontban, azonban kiemeli a stratégiai megközelítést, mely leginkább egyfajta hozzáállást és látásmódot tükröz. Mindezen technológiák jelenléte és hatékony bevezetése a városok mindennapjaiba a versenyképes társadalmi-gazdasági rendszer alapköve. Chourabi és szerzőtársainak (2012) megközelítése különbözik a smart városokat jellemző indikátorok számában, ugyanis a következő elemeket különböztetik meg:

- menedzsment és szervezés,

- technológia,

- kormányzás, 
- szakpolitikai összefüggések,

- közösségek,

- gazdaság,

- múszaki infrastruktúra,

- illetve természeti környezet.

Utóbbi szerzők szerint e dimenziók adják azt a keretet, melyen belül a smart városok múködnek, egyben a legfőbb kontextusokat is külön értékelték ki. Yamagata és Seya (2013) a smart városok definíciójából kiemelik az innovatív megoldásokat, konkrétan sarokkőnek tekintik az elektromos jármúvek bevezetését, tekintettel csökkentett szén-dioxid-kibocsátásukra, vagyis átvitt értelemben a környezeti fenntarthatóság elérésének eszközeként szerepelnek az innovatív megoldások. Kramers és szerzőtársai (2014) szintén innováció-központú megközelítést alkalmaztak, egyben kifejtették a kvaterner szektor ${ }^{2}$ szerepét a versenyképes városok létrejöttében, melyek hozzájárulnak a gazdasági és a társadalmi fenntarthatósághoz, s egyben a hatékonyabb technológiák a környezeti fenntarthatóságot is támogatják. A smart cityk között kiemelték a magas hozzáadott értékú iparágak, a digitális világ, illetve a marketing szerepét. Caragliu és szerzőtársai (2011), valamint Hollands (2008) ugyancsak az IKT-k szerepét helyezték elötérbe annak érdekében, hogy a városok hatékony és fenntartható módon legyenek képesek allokálni felhasznált erőforrásaikat, illetve szabályozni a városon belüli mobilitást.

Trindade és szerzőtársai (2017) külön definiálják a fenntarthatóság támogatását a smart eszközök által, ugyanis a smart várost szerintük a humán és társadalmi tőke tekintetében olyan befektetések jellemzik, melyek a hagyományos közlekedési rendszerek és az IKT-megoldások segítségével növelik a jóllétet, továbbá biztosítják a fenntartható gazdasági növekedést, az erőforrásokkal való fenntartható gazdálkodással és a széles körú társadalmi bevonással karöltve.

A hazai okos település jogszabályi definíciója a 314/2012. (XI.8.) Korm. rendelet 2. $5 \mathrm{a}$ és $5 \mathrm{~b}^{3}$ pontjában található, miszerint:

„5a. okos város: olyan település, amelyik az integrált településfejlesztési stratégiáját okos város módszertan alapján készíti és végzi; $5 \mathrm{~b}$. okos város módszertan: települések vagy települések csoportjának olyan településfejlesztési módszertana, amely a természeti és épített környezetét, digitális infrastruktúráját, valamint a települési szolgáltatások minőségét és gazdasági hatékonyságát korszerú és innovatív információtechnológiák alkalmazásával, fenntartható módon, a lakosság fokozott bevonásával fejleszti”. A jelen tanulmányban szerepló módszertan kidolgozásakor az integrált településfejlesztési stratégia (ITS) és az okos város módszertan kölcsönkapcsolatainak értékelését nem szúkítettük le kizárólag a jogszabály szerinti okos város kategóriára,

2 A tercier szektorból kivált negyedik gazdasági szektor, amely az információ tárolásával, feldolgozásával és továbbításával kapcsolatos tevékenységeket (például számítástechnika, média), továbbá a felsőoktatást és a kutatásfejlesztést $(\mathrm{K}+\mathrm{F})$ foglalja magában.

${ }^{3}$ Beiktatta: 56/2017. (III. 20.) Korm. rendelet 3. S (1). Hatályos: 2017. március 21-től.

Területi Statisztika, 2020, 60(3): 370-390; DOI: 10.15196/TS600304 
hanem egy univerzálisan alkalmazható, adott települések „okossági fokának” megállapítására alkalmas és a hatékony stratégiai tervezést támogató eszközt alakítottunk ki. A javasolt okos város módszertan a jogszabályi definícióval összhangban áll, mely scorecard alapú keretrendszer az elvárt szempontokon túlmenően továbbiak figyelembevételére is alkalmas a kialakított indikátorrendszer és smart planning módszertan alapján.

Az okos város módszertan megalapozása során nemcsak a hazai jogszabályi környezetnek való megfelelőséget vizsgáltuk, hanem alapvető kérdésnek tekintettük a fogalom körül zajló akadémiai-kritikai és szakpolitikai diskurzusok témakörét is. A hazai akadémiai szakirodalom jellemzően vagy adott céloknak megfelelő elemzésekkel vagy gyakorlatorientált eset-, illetve hatástanulmányokkal foglalkozik, sok esetben a helyi érintettek bevonásával (Fehér 2016). A keretrendszer esettanulmányokban történő alkalmazásához és a továbbfejlesztési elképzelések gyakorlati megvalósításához a hazai szakirodalom kitér az okos város követelményrendszerekkel kapcsolatos alapvető kérdések megválaszolására és a helyi döntéshozókkal történő egyeztetésre is. Például arra, hogy egy országos mércéhez való hasonlitás és pozicionálás, vagy a települések saját magukhoz viszonyított teljesítményének, előrehaladásának értékelése-e a célravezetőbb (Kolossa 2018). A tanulmányban szereplő módszertan, illetve annak gyakorlati alkalmazása az adott városok monitoringjával a helyi élhetóség felé történő elmozdulás irányának és nagyságának adott időszakonkénti összehasonlítását is lehetővé teszi. Vagyis a település ilyen jellegű teljesítménye tükrözi a helyi sajátosságokat, melyek a kialakított indikátorrendszer jellegében is megmutatkoznak. Egedy (2017) szerint az okos város projektek alapvetóen 3 szinten tervezhetők, mégpedig országos, települési és helyi szinteken (például városi laboratóriumok). Az okos városhoz kapcsolódó vizsgálatokban, projektekben az innovatív és a kreatív város szempontú megközelítések egyelőre kevésbé kerültek előtérbe. Megállapítása szerint az állami, az önkormányzati szerep a célok lehatárolására, a folyamat és a szereplók koordinálására vonatkozik, a piaci szereplók pedig az alkalmazható termékek és szolgáltatások biztosításáért felelősek. A folyamat gyakorlati megvalósításában azonban fontos szerepük van a helyi érintetteknek. A közösségi informatikai megoldások alkalmazása is hozzájárulhat az okos város jellegú folyamatok megerősítéséhez (Molnár 2016).

A hazai okos város témakör vizsgálata során a Lechner Tudásközpont által kialakított Okos Város Fejlesztési Modell és az emellett - a hazai települések részvételével - kidolgozott a Településértékelési és Monitoring Rendszert (Szemere-Rab 2016) használják. Utóbbi rendszer a települések okosságának mérhetőségére fókuszál. A modell kialakítási irányelvei és értékelési szempontjai között nem jelennek meg a fenntartható környezet- és erőforrás-gazdálkodási szempontok, melyek egy adott város - legyen az bármilyen okos is - alapvető élhetőségének kulcsát jelenthetik. A fenntarthatóság kizárólag gazdasági megközelítésben jelenik meg, figyelmen 
kívül hagyva a környezeti és társadalmi dimenziókat, valamint a teljességre törekvő szemléletmódban rejlő szinergikus hatások azonosításának lehetőségét.

Az okos városok fogalma több irányból is értelmezhető, jellemzően a technológiai és a társadalmi központú megközelítések állnak a különböző városkutatással foglalkozó szakemberek érdeklődésének a középpontjában (Baji 2017). Míg a múszaki-technológia témakört középpontba helyező megközelítések alapvetően ezekben keresik a komplex városi problémák megoldásának kulcsát, addig a másik irányzat a helyi érintettek bevonásán alapuló megoldások előtérbe helyezésével véli annak megtalálását, a smart eszközöket inkább a jövő városainak élhetőségét a közösségi alapú fejlesztések elősegítésével támogató eszközként értelmezve. A helyi érintettek közül hangsúlyozandó a helyi döntéshozók, leginkább a polgármesterek fenntarthatósági prioritásai (Lengyel 2017), melyek a smart city koncepciók jellegének kialakítását is jelentős mértékben befolyásolhatják. Az okos város fogalmának értelmezése sok esetben attól is függ, hogy ki fogalmazza meg azt a definíciót: helyi döntéshozó, IT-szakember, kutató, városfejlesztő, helyi lakos stb. (Lados-Tóth 2019). Az okos városok mérésének társadalmi központú megközelítése is alapvetően a helyi lakosok szubjektív érzéseire, attitűdjére fókuszál (Barsi 2019), mely a fenntartható és a smart városfejlesztési koncepciók egyik kapcsolódási pontjának is tekinthető.

A kompakt városok témaköre a fenntarthatósági és a smart témaköröknél régebben jelent meg a városfejlesztés területén. Fogalmának tisztázása mégis szükséges, mivel az gyakran keveredik a másik kettővel.

A kompakt városok letisztult fogalmi háttére egyrészt az említett nagyobb kutatási múlt, másrészt a probléma alapvetően műszaki jellegével magyarázható. A jelenlegi városkutatásokban ezért már nem a jelenség definiálása, hanem annak bemutatása és gyakorlati alkalmazása áll a középpontban (Artmann et al. 2019, Bunker et al. 2017, Tsuboi et al. 2016, Ahmadian et al. 2019, Adelfio et al. 2018). A kompakt város jellemzői: sűrűn lakott és beépített városi szövet, ahol az alközpontok és ebből fakadóan az értékek sűrűsége is megnő. Kevert használatra vonatkozó megállapítások: különböző szolgáltatások érhetők el, valamint horizontális és vertikális értelemben is kevert a használat.

A szakirodalmi áttekintés után lehetôség nyílik az egyes várostípusok közötti kapcsolatok felvázolására. A 2. ábrán azokat az előnyöket és/vagy szolgáltatásokat mutatjuk be, melyek alapvetően meghatározzák a lehatárolt várostípusok közötti, kvázi együttmúködést. Várostípuson természetesen nem azt kell érteni, hogy egy fenntartható város nem lehet kompakt, vagy pedig smart, éppen ellenkezőleg, ezen típusok egymással párhuzamosan, egy időben is jellemezhetnek egy adott városi területet.

Alapvetően a kompakt város tulajdonságait figyelembe véve egy olyan városszövetet vizsgálhatunk, amely a sűrú beépítettsége okán számos fenntarthatósági előnyt tud nyújtani. Így kijelenthető, hogy a fenntartható város egyik, bár nem kizárólagos kritériuma a kompakt városszerkezet. Napjainkban újra feléledtek a tudományos

Területi Statisztika, 2020, 60(3): 370-390; DOI: 10.15196/TS600304 
viták a kompakt városszerkezet és a fenntarthatóság egyértelmú, vagy éppen bonyolult kapcsolatáról, azonban ez az állítás a kompakt és a fenntartható városok témakörében alapvetően igazolódni látszik. A kompakt város mindezek mellett, a smart városok egyik alapját, az adatokat is szolgáltatja, mégpedig városszöveti sajátosságai okán igencsak méretgazdaságos formában. Ez utóbbi tulajdonság az, ami igazán fontos pillérévé teszi az okosság elérésének folyamatában, ugyanis a kisebb fajlagos építési és fenntartási költségek mind-mind hozzájárulnak a szolgáltatott adatok mennyiségének növeléséhez. Ezeket az adatokat végül a smart város az IKT-k révén használja fel az erőforrások optimális elosztása érdekében.

Ezzel el is érkeztünk a smart és a fenntartható város közötti, igen vékony határmezsgyére, ugyanis a szakirodalmi áttekintés alapján megállapítható, hogy egy smart város a modern technológiákon keresztül szolgáltatásokat nyújt, amelyek összességében növelik a város fenntarthatóságát. Az erőforrás-gazdálkodás említett optimalizálása, illetve a szinte összes ágazatban megjelenő innovatív megoldások mindmind hozzájárulnak a városok fenntarthatóbbá válásához, a csökkentett szén-dioxidkibocsátás, a kevesebb hulladékmennyiség, vagy éppen a megnövelt hatékonyság révén. Mindezek összefoglalásaként megállapíthatjuk, hogy a smart város nyújtja azokat a technológiákat és szolgáltatásokat, melyek egy fenntartható város kialakulásához vezethetnek, mindehhez felhasználja a kompakt városokból származó információkat. Így összekötő kapocsnak, illetve egyfajta katalizátornak tekinthetjük a városi fenntarthatóság eléréséhez vezető úton.

A smart, a kompakt és a fenntartható város fogalomrendszerének összefüggései Correlations between smart, compact and sustainable city concepts

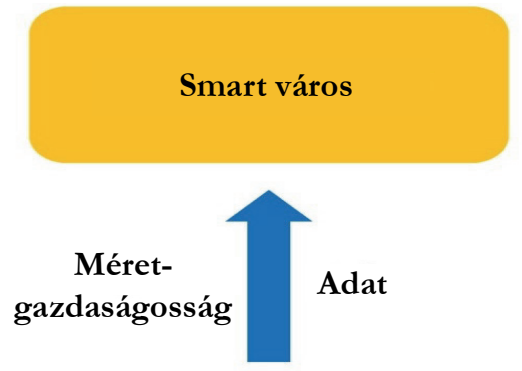

Szolgáltatások

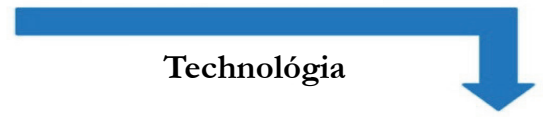

Fenntartható város
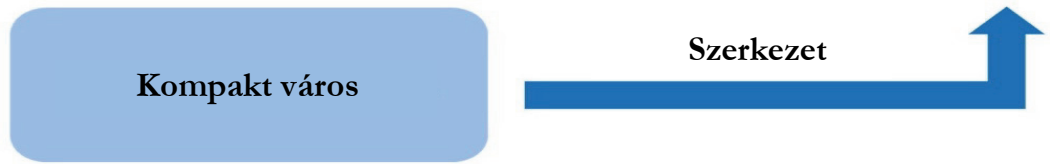

Területi Statisztika, 2020, 60(3): 370-390; DOI: 10.15196/TS600304 


\section{Fogalomalkotás}

Jelen fejezetben az indikátorok általános használatának bemutatása után az hazai viszonyokra érvényes specifikus keretrendszer alapjául szolgáló definíciókat határoljuk le. E fogalmi lehatárolások tették lehetővé a széles körű szakirodalmi indikátorkutatás után egy olyan indikátorkészlet meghatározását, melynek segítségével a rendelkezésre álló technológiai lehetőségek és a smart koncepció helyi értelmezése közötti kapcsolat feltárhatóvá vált. Az indikátorok használata a teljesítményértékelés támogatására nem új keletú, hiszen például az ISO 14031-es szabványban már régóta használják ezt a módszert a vállalatok környezeti teljesítményének értékelésére (Scipioni et al. 2008). A városi fenntarthatóság értékelése, így a smart városok jellemzése is nagymértékben különbözik az említett példától, mivel itt nemcsak a környezeti, hanem a társadalmi és a gazdasági fenntarthatóságot is értékelni szükséges az alkalmazott technológiák nyújtotta előnyök mellett. E komplexitás figyelembevétele során már nehézségekbe ütközünk, mivel azt könnyebben oldjuk meg, ha külön választjuk meg a mutatószámokat és külön értékeljük a smart városok dimenzióit, mint a hat dimenziót egy mutatón belül. Ettől függetlenül kétségtelen, hogy az említett szabvány és az alkalmazása során felhalmozott tapasztalat segítette a városi fenntarthatóságot és a városok smart technológiáit értékelő indikátorkészletek kidolgozását. Jelen kutatásban az indikátorok lehatárolásának és kiválasztásának első lépése a vizsgált rendszer, vagyis az okos város definíciójának megalkotása volt, amihez az ismertetett nemzetközi és hazai definíciókat használtuk fel. Mindezek alapján a továbbiakban smart városon a következőt értjük: minőségi fejlődést előtérbe helyező, versenyképes és innovatív település, ahol a fenntartható fejlődés eszmeisége dominál, a XXI. század technológiáira fókuszálva. Ezen fejlődés megjelenik az önkormányzat, az egyének és a társadalom egésze szintjén, egyaránt hozzájárulva az élhető település kialakításához.

A definíció szerint értelmezett városban a legelterjedtebb dimenziókat használtuk, vagyis a gazdaság, a társadalom, a környezet, a közlekedés, a kormányzás és a jóllét kategóriáin belül határoztuk meg a vizsgálni kívánt folyamatokat. Ezen lépés előtt szükséges a felsorolt dimenziók meghatározása is, amelynek segítségével tisztább képet kaphatunk az összetevőkról, ́́gy azt is tudni fogjuk, hogy mit is szeretnénk mérni. Ehhez igazítva az indikátorokat egy hatékony értékelő rendszert definiálhatunk. A következő definíciókban a dimenziók angol nyelvű elnevezésekkel szerepelnek, az egyszerúbb összehasonlíthatóság és a magyar szakirodalomban nem egységes elnevezésekből adódó problémák elkerülése érdekében.

Smart economy: innovációra épülő, foglalkoztatást elősegítő és a vállalkozói kedvet ösztönző, produktivitást támogató és a smart business megoldásokat elótérbe helyező, valamint a turizmusfejlesztésre is koncentráló gazdasági szerkezet. Alkategóriák: innováció, foglalkoztatás elősegitése, vállalkozói kedv ösztönzése, produktivitás támogatása, smart business megoldások ösztönzése, turizmus fejlesztése.

Területi Statisztika, 2020, 60(3): 370-390; DOI: 10.15196/TS600304 
Smart people: képzett, kreatív és együttmúködő társadalmi berendezkedés, amelyben a városlakók nyitottak az innovatív IKT-megoldások, illetve elkötelezettek az élethosszig tartó tanulás iránt. Alkategóriák: képzettség, kreativitás, együttmúködés, nyitottság az IKT-megoldások iránt, elkötelezettség az élethosszig tartó tanulás iránt.

Smart governance: transzparens múködésű, a társadalom széles körének bevonása a döntéshozatali folyamatokba, e-kormányzási eszközökkel a hatékony és optimális működési szint elérése érdekében. Alkategóriák: transzparens múködés, társadalom bevonása a döntésekbe, e-kormányzási eszközök használata, hatékony és optimális múködés.

Smart mobility: olyan közlekedési rendszer, amelyik a rendelkezésre álló adatokat IKT-k segítségével optimalizálja annak érdekében, hogy a helyi társadalom életminôsége érezhetô mértékben javuljon a smart infrastruktúra, illetve a zöld és a nem motorizált közösségi, valamint egyéni közlekedési módok biztonságot nyújtó használatával. Alkategóriák: smart közlekedési infrastruktúra, IKT-megoldások az egyéni közlekedésben, közösségi közlekedés, nem motorizált egyéni közlekedés, zöld közlekedés, biztonságos közlekedés.

Smart environment: fenntartható környezet- és erőforrás-gazdálkodással jellemezhetô, a jövő változásaira rendszer szinten rugalmasan reagáló, dinamikus, a természeti tőkét tiszteletben tartó és a megelőzésre odafigyelő élettér. Alkategóriák: fenntartható környezet- és erőforrás-használat, rugalmas reagálás, dinamizmus, természeti tôke tisztelete, megelőzés.

Smart living: olyan városi élettér, melyet a biztonság, az IKT-hoz való hozzáférés, az egészséges, kultúraorientált és elégedett városi közösség jellemez, megfelelő életkörülmények biztosítása mellett. Alkategóriák: biztonság, egészség, IKT-hoz való hozzáférés, kultúra, elégedettség.

$\mathrm{Az}$ indikátorkészlet megalkotásánál tehát az egyes aldimenziók szerinti bontás mentén határoztuk meg a különféle mutatókat. A felhasznált indikátorok széles körú szakirodalmi elemzésen alapulnak, és az adaptálhatóságra tekintettel a projekt szempontjából kiemelt jelentőségú mutatókkal egészítettük ki. Az irodalomelemzés során 23 olyan nemzetközileg is releváns kutatást tekintettünk át, amelyben összesen 796 indikátor szerepelt, melyek jó eséllyel - bizonyos helyi adottságokhoz igazított átalakítás után - használhatónak bizonyultak projektünkben. Az indikátorok dimenziónkénti megoszlása, sem az egyes vizsgált irodalmakon belül, sem azok között nem volt egyenletes, az eltérő fogalommagyarázat következtében.

\section{Indikátorfejlesztési folyamat}

A hazai és a nemzetközi szakirodalmi feltárás alapján lehatárolt indikátorkészletek tanulmányozását követően azokat szűrtük, illetve teljesen egyedi indikátorokat alkottunk a helyi viszonyokhoz való alkalmazkodás igényének kielégítésére. Az indikátor- 
fejlesztési folyamat végén a 6 kategórián belül - az ismertetett definíció alapján 31 alkategóriában, összesen 222 indikátort határoztunk meg, melyek esetében a változók közötti minőségi átfedés és az így jelentkező duplumok elkerülése érdekében korrelációvizsgálatot végeztünk. Az egyes kategóriák között törekedtünk - a tartalmi függőség elkerülése mellett - a mérőszámok egyenletes eloszlására, így az indikátorok közül 47 került a smart economy kategóriába, 29 a smart people értékeit méri, 28 reflektál a kormányzási kérdésekre, 45 a közlekedési szektor teljesítményét monitorozza, 36 a környezeti dimenzióhoz kapcsolódik, míg végül 37 a smart living kategóriába került. A terjedelmi korlátok miatt jelen tanulmányban a smart environment kategórián belül lehatárolt scorecard alapú indikátorokat és az alkategóriákat mutatjuk be mintaként. A scorecard típusú indikátoralkotás fontos sarokköve lesz a következő fejezetben ismertetendő smart planning értékelési és várostervezési eszköznek, mivel a mutatószámokban bekövetkező változások alapvetô fontosságúak a városfejlesztési eszközök ex ante értékelése során. Az okos környezet dimenzión keresztül bemutatott indikátorválasztási és -alkotási folyamat pontosan megegyezik a többi öt smart dimenzió esetében követett gondolatmenettel.

A megoldandó módszertani problémák között a legfontosabb volt az elérhető, illetve potenciálisan megszerezhetô, egyben releváns indikátorok felkutatása és a vizsgált területet a legnagyobb magyarázó erővel leíró tulajdonságok összehangolása volt. Ezt a gyakorlatban az adat-, illetve információvezérelt indikátorválasztási módszertannal szemléltethetjük. Míg előbbi esetben a nyilvánosan vagy az önkormányzat által belső adatszolgáltatás útján elérhető információk köre határozza meg az indikátorkészletet, addig az utóbbiban a szakértői bázison alapuló adatigényt szerepeltetjük, ami rendszerint jelentősen meghaladja a rendelkezésre álló mutatószámok körét. Az 1. táblázatban bemutatott indikátorok kiválasztásában és megfogalmazásában hibrid megoldást választottunk: megvizsgáltuk az elérhető statisztikai adatok körét, azokat az indikátorokat, amelyeket az adott önkormányzat az illetékességi területén belül adatszolgáltatási kérelemmel előállíthat, illetve azokat a mutatószámokat is figyelembe vettük, melyek az információvezérelt indikátoralkotás szerint a lehető legpontosabban jellemzik a vizsgált alkategóriákat. A rendelkezésre álló adatok körén túl kifejezetten hangsúlyos volt az indikátorok alrendszerekbe történő csoportosítása is, melynél a következő elvet követtük: a korábbiakban meghatározott smart dimenziók tulajdonságai, valamint a hazai és a nemzetközi szakirodalomban szereplő smart city jellemzők figyelembevételével alakítottuk ki az alkategóriákat. A smart environment területén így külön csoportba kerültek a megelőzéssel, a fenntartható környezet- és erőforrás-gazdálkodással, valamint a rugalmasan reagáló és dinamikus környezettel kapcsolatos mérőszámok.

Területi Statisztika, 2020, 60(3): 370-390; DOI: 10.15196/TS600304 


\section{A scorecard alapú indikátorlista a smart environment területén} Scorecard based indicator list for smart environment

\begin{tabular}{c|c|c}
\hline Indikátor & $\begin{array}{c}\text { Mérték- } \\
\text { egység }\end{array}$ & $\begin{array}{c}\text { Elvárt } \\
\text { érték/ } \\
\text { változás }\end{array}$ \\
\hline
\end{tabular}

Csőrepedések és elfolyások száma

Megelőzés alkategória

Csatornahálózatra felszerelt szenzorok, kamerák száma

Gázhálózatra felszerelt szenzorok, kamerák száma

Villamos hálózatra felszerelt szenzorok, kamerák száma

Csatornahálózat megfigyelésének területnagysága

Gázhálózat megfigyelésének területnagysága

Villamos hálózat megfigyelésének területnagysága

Áramkimaradásos percek számaa)

Áramkimaradások számab)

Fenntartható környezet- és erőforrás-gazdálkodás

Teljes energiahasználat/fó

Teljes energiahasználat/fô az önkormányzati fenntartású intézményekben

Önkormányzati fenntartású intézmények megújulóenergia-használata

Civil és lakossági megújulóenergia-használat

Önkormányzati fenntartású intézmények LED használata

Szelektíven gyüjtött hulladék aránya - önkormányzat

Szelektíven gyújtött hulladék aránya - lakosság és civilek

Szelektíven gyűjtött hulladék aránya - vállalat

Szelektíven felhasznált hulladék

Rugalmasan reagáló és dinamikus környezet

3. tisztítási fokozattal megtisztított szennyvíz aránya

Adaptációs intézkedések száma

Agrár-környezetgazdálkodásba bevont terület aránya

Biogázból származó energia aránya (termelés)

Szélerőművektől származó energia aránya (termelés)

Biomasszából származó energia aránya (termelés)

Napenergiából származó energia aránya (termelés)

Vízenergiából származó energia aránya (termelés)

Okos energiaelosztó hálózatra kötött lakások száma

Okos energiaelosztó hálózatra kötött önkormányzati intézmények száma

Smart mérési központok által lefedett terület nagysága

Önkormányzati környezetvédelmi kiadások aránya

Lakossági környezetvédelmi kiadások aránya

Vállalati környezetvédelmi kiadások aránya

Háztartási méretű kis erőművek száma

Háztartási méretű kis erőművel megtermelt energia mennyisége

Lakossági + Civil szén-dioxid-emisszió

Önkormányzati üzemeltetésű intézmények szén-dioxid-emisszió

\begin{tabular}{c|c}
$\mathrm{db}$ & $\downarrow$ \\
$\mathrm{db}$ & $\uparrow$ \\
$\mathrm{db}$ & $\uparrow$ \\
$\mathrm{db}$ & $\uparrow$ \\
$\mathrm{km}^{2}$ & $\uparrow$ \\
$\mathrm{km}^{2}$ & $\uparrow$ \\
$\mathrm{km}^{2}$ & $\uparrow$ \\
$\mathrm{perc}$ & $\downarrow$ \\
$\mathrm{db} /$ fel- & $\downarrow$ \\
használó & $\downarrow$
\end{tabular}

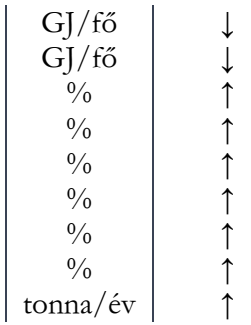

a) Fogyasztónkénti üzemzavari kiesési idők összege / összes fogyasztószám (System Average Interruption Duration Index [SAIDI], magyarul MEH 2 mutató).

b) Az üzemzavarok során érintett fogyasztók száma / összes fogyasztószám (System Average Interruption Frequency Index [SAIFI], magyarul MEH 1 mutató).

Területi Statisztika, 2020, 60(3): 370-390; DOI: 10.15196/TS600304 
Az indikátorok kiválasztása során további fontos szempont volt, hogy az adott alkategórián belül az ésszerűség határát ne lépje át a mutatók száma, mivel egy túlságosan szerteágazó és inkluzív értékelési rendszer ugyan tudományos szempontból minden bizonnyal teljesebb lenne, azonban az egyik fő célunk a gyakorlati alkalmazhatóság volt. Ezen a ponton feltétlenül figyelembe kellett venni a területi fókuszt, vagyis olyan indikátorokra volt szükség, amelyek adaptálhatók a hazai viszonyokra, lehetőséget adnak az értékelésbe bevont városok számára az átalakításra, és mindemellett nem veszítenek magyarázó jellegükből. Ezen peremfeltételek mentén a megelőzési alkategóriában összesen 9 indikátort határoltunk le, melyek jellemzően az okos rendszerek egyik alapkövét jelentő infrastrukturális hálózatok állapotát és minőségi ismérveit fejezik ki. A megelőzést tehát ebben az esetben az üzemszünetek és az ezzel kapcsolatos károk preventív jellegén keresztül kell érteni. Fenntarthatósági szempontból az erőforrás-gazdálkodási kérdések nem kerülhetôk meg, így a második alkategóriában (Fenntartható környezet- és erőforrás-használat) meghatározott 9 indikátor a fenntartható hulladék- és energiagazdálkodás lakossági, önkormányzati és vállalati aspektusaira mutat rá, szem előtt tartva az elérhetô indikátorok viszonylag szúkebb körét. A legtöbb (18) mutatószám a „Rugalmasan reagáló és dinamikus környezet" alkategóriában szerepel. A felülreprezentáltság oka, hogy - véleményünk szerint - a jövő okos és fenntartható városai körében alapkövetelmény a megváltozó körülményekhez való rugalmas alkalmazkodás, mely a decentralizált energiatermelésen, az üvegházhatású gázok kibocsátásának csökkentésén, a klímaváltozáshoz való alkalmazkodáson, illetve a smart energiaellátó rendszerek elterjedésén keresztül ragadható meg. Ahogy a korábbiakban is említettük, jelen tanulmányban terjedelmi korlátok miatt nem mutatjuk be az összes indikátort, azonban a tárgyalt indikátoralkotási folyamat egyes lépcsőit, úgymint az elérhető információk körét vagy a smart dimenziót leíró alkategóriákhoz való kapcsolódást minden esetben kiemelten fontosnak tekintettük, a statisztikai értelemben vett függetlenség mellett. A lehatárolt indikátorok kiválasztásánál végezetül döntő szempont és közös feltétel volt az értékelési keretrendszer rugalmas alakíthatósága és átjárhatósága, mely a következő fejezetben bemutatott smart planning módszertan nulladik feltételeként értelmezendő.

\section{Smart planning}

Az egyes smart beruházások városfejlesztési célokhoz való rögzítése, illetve összekötése olyan innovatív megoldásokkal járul hozzá a fenntartható és a smart városok kialakulásához, melyeket jellemzően a vállalati szféra képes az önkormányzatok részére szolgáltatni. Ennek érdekében kialakítottuk az ún. smart planning értékelési rendszert, mely 3 fő lépéssel éri el a megfogalmazott fő célt. A modell múködésének célja, hogy megfelelő támpontot adjon a gazdasági, üzleti szereplők számára egy adott településen megvalósítható fejlesztésekhez. A fejlesztéseket természetesen az

Területi Statisztika, 2020, 60(3): 370-390; DOI: 10.15196/TS600304 
adott vállalati szereplő szabja meg, vagyis azoknak specifikusnak kell lenniük, továbbá illeszthetônek a település jövőbeli fejlesztési céljaihoz, különböző időtávokra vonatkozó elképzeléseihez.

Első lépésben az adott városra jellemző integrált településfejlesztési stratégiában (ITS) szereplő célokat és beavatkozásokat smart alkategóriákhoz rögzítik, melynek segítségével közvetett kapcsolat alakul ki az indikátorokkal is. Ezen a ponton tehát az értékelési rendszer az adott városra már specifikus lesz, hiszen az egyedileg megállapított ITS-célok találkoznak a korábban meghatározott smart alkategóriákkal. A 2. táblázatban a smart planning első lépését mutatjuk be a Győr ITS-ében ${ }^{4}$ szereplő beavatkozások alapján: a legfelső sorokban a smart dimenziók és az egyes alkategóriák találhatók, melyet a városra jellemző tematikus ITS-célok követnek. Az így felvázolt kapcsolat azonban kétirányú is lehet, amelyet a smart planning második lépésében tárunk fel.

2. táblázat

A smart planning első lépése

The first step of smart planning

\begin{tabular}{|c|c|c|c|}
\hline Smart dimenzió & \multicolumn{3}{|c|}{ Smart environment } \\
\hline Alkategóriák & $\begin{array}{c}\text { Fenntartható környezet- és } \\
\text { erőforrás-használat }\end{array}$ & $\begin{array}{l}\text { Rugalmasan reagáló és } \\
\text { dinamikusan környezet }\end{array}$ & Megelőzés \\
\hline \multirow{6}{*}{ Smart planning } & $\begin{array}{l}\text { Hulladékgazdálkodás; } \\
\text { hulladékhasznosítás }\end{array}$ & $\begin{array}{l}\text { Minimális környezet- } \\
\text { terheléssel járó, nagy } \\
\text { ellátási biztonságot nyújtó } \\
\text { megoldások előnyben } \\
\text { részesítése }\end{array}$ & $\begin{array}{l}\text { Mikroklimatikus hatás } \\
\text { biztosítása }\end{array}$ \\
\hline & $\begin{array}{l}\text { Barnamezős területek } \\
\text { revitalizációja }\end{array}$ & Mederrendezések & $\begin{array}{l}\text { Szennyvízelhelyezés és } \\
\text {-kezelés, csapadékvíz- } \\
\text { elvezetés, hálózat- } \\
\text { rehabilitáció }\end{array}$ \\
\hline & $\begin{array}{l}\text { A területtel és termőföld- } \\
\text { del való takarékos gazdál- } \\
\text { kodás érvényesítése }\end{array}$ & $\begin{array}{l}\text { Hullámterek zöldfelületi } \\
\text { rendszerbe kapcsolása, } \\
\text { vízparti sétányok össze- } \\
\text { függổ közhasználatú } \\
\text { rendszerének kialakítása }\end{array}$ & Árvízvédelem, vízrendezés \\
\hline & $\begin{array}{l}\text { Meglévő épületállomány } \\
\text { energiatakarékos } \\
\text { rekonstrukciója }\end{array}$ & $\begin{array}{l}\text { A víz, a levegö, a talaj, } \\
\text { a klíma és az élővilág } \\
\text { védelme }\end{array}$ & \\
\hline & Panelprogram folytatása & & \\
\hline & $\begin{array}{l}\text { Alacsony energiafogyasz- } \\
\text { tású és passzív házak épí- } \\
\text { tésének támogatása, támo- } \\
\text { gatási rendszer kiépítése }\end{array}$ & & \\
\hline
\end{tabular}

${ }^{4}$ http://innovacio.gyor.hu/data/files/varosfejlesztesiosztaly/its/gymjv_its_jovahagyott_2014.09.12_javitott.pdf

Területi Statisztika, 2020, 60(3): 370-390; DOI: 10.15196/TS600304 
A smart planning folyamat második lépése az indikátorok és a korábban alkategóriákhoz tartozó ITS-beavatkozások összekapcsolása, a közvetlen és a közvetett hatások feltárása. Mint azt a korábbiakban említettük, kiemelt szerepet kap a scorecard alapú indikátorképzés. A 3. táblázat bemutatja, hogy egy egyszerú táblázatkezelő szoftverben a „Fenntartható környezet- és erőforrás-használat” alkategória, valamint a hozzá tartozó indikátorok hogyan állnak kapcsolatban a smart planning első lépésével. A módszertan e szakasza ismételten helyspecifikus, hiszen adott település esetében az indikátorok értékei mellett figyelembe kell venni a városfejlesztési dokumentumok alapján meghatározott célértékeket, vagy ennek hiányában a mutatószámban bekövetkező változás irányát. Fontos megjegyezni, hogy a 3. táblázatban szereplő értékek minden esetben fiktívek, mindössze a példa bemutatása érdekében határoztuk meg őket. A táblázat jobb áttekinthetősége érdekében pedig a korábban az alkategóriához tartozó 9 környezeti indikátort Env1-Env9 kódokkal jelöltük.

3. táblázat

\section{A smart planning második lépése}

The second step of smart planning

\begin{tabular}{|c|c|c|c|c|c|c|c|c|c|}
\hline Alkategória & & & enntart & ató kö1 & yezet- $c$ & erőfor & shasznà & & \\
\hline Indikátor & Env1 & Env2 & Env3 & Env4 & Env5 & Env6 & Env7 & Env8 & Env9 \\
\hline Mértékegység & GJ/fö & $\mathrm{GJ} /$ fô $^{\prime \prime}$ & $\%$ & $\%$ & $\%$ & $\%$ & $\%$ & $\%$ & tonna/év \\
\hline Jelenlegi érték & 30 & 50 & 27 & 10 & 20 & 45 & 14 & 12 & 120 \\
\hline Elvárt állapot & 20 & 35 & 35 & 40 & 40 & 55 & 30 & 25 & 250 \\
\hline Elvárt irány & $\downarrow$ & $\downarrow$ & $\uparrow$ & $\uparrow$ & $\uparrow$ & $\uparrow$ & $\uparrow$ & $\uparrow$ & $\uparrow$ \\
\hline \multirow{6}{*}{$\begin{array}{l}\text { Smart planning, } \\
\text { ITS alapján }\end{array}$} & \multicolumn{9}{|c|}{ Hulladékgazdálkodás; hulladékhasznosítás } \\
\hline & \multicolumn{9}{|c|}{ Barnamezős területek revitalizációja } \\
\hline & \multicolumn{9}{|c|}{ A területtel és a termőfölddel való takarékos gazdálkodás érvényesítése } \\
\hline & \multicolumn{9}{|c|}{ Meglévő épületállomány energiatakarékos rekonstrukciója } \\
\hline & \multicolumn{9}{|c|}{ Panelprogram folytatása } \\
\hline & \multicolumn{9}{|c|}{$\begin{array}{c}\text { Alacsony energiafogyasztású és passzív házak építésének támogatása, } \\
\text { támogatási rendszer kiépítése }\end{array}$} \\
\hline
\end{tabular}

A módszertan harmadik lépésében smart és fenntartható városfejlesztési elvek mentén egységbe foglaljuk az önkormányzati szféra keresletét és a versenyszféra kínálatát annak érdekében, hogy az adott város a megfogalmazott célkitűzéseihez megtalálja a legmegfelelőbb vállalati megoldást. Ebben a lépésben tehát a megalkotott smart city keretrendszert a meghatározott indikátorokon keresztül közvetító közegként használjuk azon innovatív megoldások kiválasztására, melyek szoros kapcsolatban állnak az adott város megfogalmazott fejlesztési céljaival. Egy kiválasztott technológia bevezetésének hatására - a korábban feltárt összefüggések alapján - egy vagy több smart alkategória egy vagy több indikátorának értéke megváltozik, amely

Területi Statisztika, 2020, 60(3): 370-390; DOI: 10.15196/TS600304 
városfejlesztési szempontból ugyancsak pozitív következményekkel jár, hiszen közelebb kerülünk egy korábban lehatárolt ITS-cél teljesüléséhez. A 4. táblázatban az előzőkben bemutatott lépéseket kiegészítettük egy fiktív vállalati megoldás nyújtotta esetleges előnyökkel és hátrányokkal. Egy adott piaci megoldás értékelése szakértői véleményeken és felméréseken alapul, vagyis ebben az esetben is egy specifikus értékelési rendszerrel és döntési háttérrel ismerkedhetünk meg. A fő kérdés az, hogy egy adott megoldás hatással van-e a smart alkategóriák indikátoraira, és ha igen, akkor számszerúsíthető-e az értéke vagy csak a változás iránya becsülhető meg. Ezen alapulva tehát összesen 5 különböző kimenet fordulhat elő: nem azonosítható, pozitív és negatív kapcsolat, utóbbiakon belül a számszerűsíthető végeredmény és a változás irányának ismerete.

4. táblázat

A piaci megoldások hatásainak értékelése a smart planning harmadik lépéseként Assessing the impact of market solutions as a third step in smart planning

\begin{tabular}{|c|c|c|c|c|c|c|c|c|c|c|}
\hline \multirow{2}{*}{\multicolumn{2}{|c|}{$\begin{array}{c}\text { Alkategória } \\
\text { Indikátor }\end{array}$}} & \multicolumn{9}{|c|}{ Fenntartható környezet- és erőforráshasználat } \\
\hline & & Env1 & Env2 & Env3 & Env4 & Env5 & Env6 & Env7 & Env8 & Env9 \\
\hline \multicolumn{2}{|c|}{ Mértékegység } & GJ/fö & GJ/fö & $\%$ & $\%$ & $\%$ & $\%$ & $\%$ & $\%$ & $\begin{array}{c}\text { tonna/ } \\
\text { év }\end{array}$ \\
\hline \multicolumn{2}{|c|}{ Jelenlegi érték } & 30 & 50 & 27 & 10 & 20 & 45 & 14 & 12 & 120 \\
\hline \multicolumn{2}{|c|}{ Elvárt állapot } & 20 & 35 & 35 & 40 & 40 & 55 & 30 & 25 & 250 \\
\hline \multicolumn{2}{|c|}{ Elvárt irány } & $\downarrow$ & $\downarrow$ & $\uparrow$ & $\uparrow$ & $\uparrow$ & $\uparrow$ & $\uparrow$ & $\uparrow$ & $\uparrow$ \\
\hline \multirow{3}{*}{ Megoldás 1} & Érték & 15 & - & - & 5 & - & - & - & - & - \\
\hline & Irány & & & - & & $\downarrow$ & - & - & - & - \\
\hline & Értékelés & $\downarrow$ & $\downarrow$ & & $\downarrow$ & $\downarrow$ & & & & \\
\hline
\end{tabular}

Megjegyzés: A cellákban a következő jelöléseket alkalmaztuk: üres - nem azonosítható kapcsolat, zöld - pozitív kapcsolat, piros - negatív kapcsolat, fekete nyíl - számszerűsíthető végeredmény, fehér nyíl - a változás iránya ismert. A táblázat fiktív értékeket és jelöléseket tartalmaz.

A gyakorlatban a smart planning ,végterméke” egy olyan automatikus múködésú jelzőrendszer, amely az üzleti világ szereplőinek és az önkormányzatoknak is smart üzleti megoldásokkal segít elérni a fenntartható városfejlesztési célok megvalósulását. Az üzleti partner részéről átláthatóvá válik, hogy az adott település esetében mely eszköz használatával tudják leginkább a település smart cityvé válását elősegíteni. Az önkormányzatok pedig képesek ex ante értékelést végezni egy adott városfejlesztési beruházásról annak függvényében, hogy a saját fenntartható városfejlesztési céljaik és beavatkozásaik milyen közvetlen és közvetett kapcsolatban állnak egy adott, javasolt piaci megoldással. A közös platform tehát jelentősen hozzájárul az erőforrások helyes és fenntartható allokálásához, mivel így smart megoldások használatával oly módon valósíthatók meg a fenntartható városfejlesztési célok, hogy a szúkös önkormányzati innovációs potenciálon túllépve a versenyszféra megoldásait 
alkalmazzuk, célzott megközelítéssel. Ezt az esetet elsődleges stratégiának nevezhetjük az önkormányzat részéről, azt viszont, amikor egy piaci szereplő által kínált smart technológia egyetlen ITS-céllal sem áll közvetlen kapcsolatban, másodlagos stratégiának, hiszen nyilvánvalóan olyan beavatkozásokat valósítanak meg első körben, melyek közvetlenül hatnak az ITS-célokra. A másodlagos stratégia elemei ugyanakkor ugyanúgy hozzájárul(hat)nak a fenntartható városfejlesztési mechanizmusokhoz, azonban kiemelt ITS-cél megvalósulását nem támogatják, „mindössze” általánosságban javítják a városlakók életminőségét. Ebben az értelemben tehát az ITS-célok és a kínált technológia közötti közvetlen kapcsolat megléte vagy hiánya különbözteti meg egymástól az elsődleges és a másodlagos stratégiát, és a megfogalmazás nem utal egyéb minőségi jellemzőre.

A kialakított smart planning értékelési rendszer alapján, a felvázolt koncepcionális keret mentén lehetőség nyililk tehát az ITS-célok smart city szempontú értékelésére, amely hozzájárul a kitörési pontok és a rendelkezésre álló hatékony, a kitúzött helyi célokat támogató termékjavaslatok, szolgáltatások azonosítására. Az értékelési rendszer használatával egy költség- és erőforrás-hatékony eszköz kerülhet a hazai önkormányzatok kezébe, melyekkel kiválaszthatják a városuk fejlesztési céljaihoz legmegfelelőbb és több szempontból is legoptimálisabb megoldásokat. A városverseny területén településmarketing szempontjából is értékes a rendszer használata, hiszen manapság számos olyan független értékelési rendszer van, mely egy város "okosságát" méri, ezáltal is versenyelőnybe hozva az adott települést. Habár a módszertan ismertetésénél több helyen is jeleztük, hogy mindkét oldal - tehát az önkormányzatok és a vállalatok - részéről is személyre szabott, specifikus értékeléseket kell készíteni a smart planning folyamatában, maga a döntéstámogatási rendszer logikája és lépései uniformizáltak, és függetlenek akár a településmérettől is. Segítségével mind az önkormányzatok, mind az üzleti szféra képviselői képesek lesznek városfejlesztési szempontból a leghatékonyabb döntést meghozni, amelyben az objektíven mérhetô és megállapítható indikátorrendszer scorecard alapú mutatószámai játsszák az elsődleges szerepet.

\section{Összefoglaló következtetések}

Jelen tanulmány keretein belül kísérletet tettünk egy smart city koncepció és annak gyakorlati leágazásainak fenntartható városfejlesztési folyamatokban való beépítésére, mely során az elméleti háttér feltárása után bemutattuk az ún. smart planning értékelési keretrendszert. A smart planning folyamatát megalapozandó egyedi, a hazai viszonyokra szabott fogalomalkotás és a kidolgozott indikátorkészlet széles körú tudományos kutatások szintézisén alapult, vagyis az elméleti összefüggések gyakorlatba való átültetésében megtettük az első lépéseket. A meghatározott smart city és a kapcsolódó dimenziók fogalmi lehatárolásánál alapvetően IKT- és projektközpontú megközelítést alkalmaztunk, melynek oka a piacon jelen lévő versenyképes vállalatok

Területi Statisztika, 2020, 60(3): 370-390; DOI: 10.15196/TS600304 
portfóliója, valamint a városfejlesztési fókusz megléte. A kidolgozott módszertan igazodik a városonként eltérő megoldásokhoz, a helyi adottságokat figyelembe véve specifikálható, ugyanakkor az alaplogika és a múködés/múködtetés továbbra is változatlan marad, vagyis a módszertan egyes elemei más hazai városokban egyaránt alkalmazhatók. Az indikátorrendszer lehetővé teszi a települések stratégiai céljainak ellenőrizhető megvalósulását, illetve a lehetséges fejlesztések és piaci megoldások ex ante értékelését. A nagyfokú rugalmasság és testre szabhatóság akár településmérettôl függetlenül is biztosítja a vállalati megoldások ex ante értékelését. A lehatárolt indikátorokkal történő értékelés segítségével akár évente is felülvizsgálhatók az előrehaladás eredményei, vagyis az ITS-célok smart megoldásokkal történő elérése, amihez természetesen az adatszolgáltatók rugalmas alkalmazkodása is szükséges. Nem lehetséges csak és kizárólag önkormányzati adatforrásokra alapozni, a lakossági elégedettség felmérése, a közmúvállalatok által szolgáltatott adatok, a rendőrség, a kórházak, a helyi egyházak és egyéb civil szervezetek folyamatos adatszolgáltatásai mind-mind elengedhetetlen és integráns részei egy jól múködő monitoringszervezetnek. A módszertan gyakorlati alkalmazása tehát nemcsak a fenntartható városfejlesztési célok eléréséhez, hanem az érdekelt felek szorosabb együttmúködéséhez is hozzájárul.

\section{Köszönetnyilvánítás}

A tanulmány alapjául szolgáló kutatást részben az Emberi Erőforrások Minisztériuma által meghirdetett Felsőoktatási Intézményi Kiválósági Program támogatta, a BME FIKP-MI/SC tématerületi programja keretében.

\section{IRODALOM}

Adelfio，M.-Kain，J. H.-Thuvander，L.-StenberG，J. (2018): Disentangling the Compact City Drivers and Pressures: Barcelona as a Case Study Norsk Geografisk Tidsskrift 72 (5): 287-304. https://doi.org/10.1080/00291951.2018.1547788.

Ahmadian, E.-Byrd, H.-Sodagar, B.- Matthewman, S.- Kenney, C.-Mills,G. (2019): Energy and the Form of Cities: The Counterintuitive Impact of Disruptive Technologies Architectural Science Review 62 (2): 145-51. https://doi.org/10.1080/00038628.2018.1535422.

Angelidou, M. (2014): Smart City Policies: A Spatial Approach Cities 41: S3-11. https://doi.org/10.1016/j.cities.2014.06.007.

Artmann, M.-Kohler, M.-Meinel, G.-Gan, J.-IojA, I. C. (2019): How Smart Growth and Green Infrastructure Can Mutually Support Each Other - A Conceptual Framework for Compact and Green Cities Ecological Indicators 96: 10-22. https://doi.org/10.1016/j.ecolind.2017.07.001.

BAJI, P. (2017): Okos városok és alrendszereik - kihívások a jövő városkutatói számára? Tér és Társadalom 31 (1): 89-105. https://doi.org/10.17649/tet.31.1.2807. 
BARSI, B. (2019): A boldogság mint az okos városok mérésének új, lehetséges módszere Terïleti Statisztika 59 (5): 555-74. https://doi.org/10.15196/TS590505.

BAтTY, M. (2013): Big Data, Smart Cities and City Planning Dialogues in Human Geography 3 (3): 274-79. https://doi.org/10.1177/2043820613513390.

Bocquier, P. (2018): World Urbanization Prospects: an alternative to the UN model of projection compatible with the mobility transition theory Demographic Research. 12 (ARTICLE 9): 197-236. https://doi.org/10.4054/demres.2005.12.9.

Bunker, R.- Crommelin, L.-Troy, L.-Easthope, H.-Pinnegar, S.-Randolph, B. (2017): Managing the Transition to a More Compact City in Australia International Planning Studies 22 (4): 384-99. https://doi.org/10.1080/13563475.2017.1298435.

Caragliu, A.-Del Bo, C.-Nijkamp, P. (2011): Smart Cities in Europe Journal of Urban Technology 18 (2): 65-82. https://doi.org/10.1080/10630732.2011.601117.

Chourabi, H.-Nam, T.-Walker, S.-Gil-Garcia, J. R.-Mellouli, S.-NAhon, K.PARDo, T. A.-SCHOLL, H. J. (2012): Understanding Smart Cities: An Integrative Framework Proceedings of the Annual Hawaii International Conference on System Sciences, no. July 2014: 2289-97. https://doi.org/10.1109/HICSS.2012.615.

DAmeri, R. P. (2012): Searching for Smart City Definition: A Comprehensive Proposal International Journal of Computers \& Technology 11 (5): 2544-51. https://doi.org/10.24297/ijct.v11i5.1142.

EGEDY, T. (2017): Városfejlesztési paradigmák az új évezredben - a kreatív város és az okos város Földrajzi Kö̊lemények 141 (3): 254-62.

FEHÉR, K. (2016): Okos város: trendtémák és koncepciók Információs Társadalom 17 (4): 25-38.

Hollands, R. G. (2008): Will the Real Smart City Please Stand up? Intelligent, Progressive or Entrepreneurial? City 12 (3): 303-20. https://doi.org/10.1080/13604810802479126.

Joss, S.-SENGERS, F.-SChraven, D.-CAProtTi, F.-DAYOT, Y. (2019): The Smart City as Global Discourse: Storylines and Critical Junctures across 27 Cities Journal of Urban Technology 26 (1): 3-34. https://doi.org/10.1080/10630732.2018.1558387.

KolossA, J. (2018): Az okos város: új esély a tudatos településfejlesztés meghonosítására Metszer: Épitész̨et, Újdonságok, Szerkežetek, Részletek 9 (4): 52-55.

Kramers, A.- HÖJER, M.-LÖVEHAGEN, N. (2014): Environmental Modelling \& Software Smart Sustainable Cities e Exploring ICT Solutions for Reduced Energy Use in Cities Q Environmental Modelling \& Software 56: 52-62. https://doi.org/10.1016/j.envsoft.2013.12.019.

LAdos, M.- TóTH, M. L. (2019): Autonóm jármúvek az okos városokban Tér, Gazdaság, Ember 1 (7): 159-73.

LENGYEL, A. (2017): A fenntarthatósági kritériumok térbeli diszkontálása Területi Statiş̨tika 57 (2): 183-204. https://doi.org/10.15196/TS570204.

LindenAu, M.-BÖHLER-BAEDEKER, S. (2014): Citizen and Stakeholder Involvement: A Precondition for Sustainable Urban Mobility Transportation Research Procedia 4: 347-60. https://doi.org/10.1016/j.trpro.2014.11.026.

Területi Statisztika, 2020, 60(3): 370-390; DOI: 10.15196/TS600304 
Lombardi, P.-Giordano, S.-FArouh, H. (2012): Innovation : The European Journal of Social Science Research Modelling the Smart City Performance Innovation: The European Journal of Social Science Research 25 (2): 137-49. https://doi.org/10.1080/13511610.2012.660325.

Lombardi, P.-Giordano, S.-Farouh, H.-Yousef, W. (2012): Modelling the Smart City Performance Innovation: The European Journal of Social Science Research 25 (2): 137-49. https://doi.org/10.1080/13511610.2012.660325.

MOLNÁR, Sz. (2016): Az okos város fejlesztésekhez kapcsolódó közösségi informatikai eszközök: társadalmi szoftver, online participáció, crowdsourcing Információs Társadalom 16 (3): 101-12. http://real.mtak.hu/id/eprint/51370.

SASSEN, S. (2005): The Global City: Introduction Concept Brown Journal of World Affair 38 (4): 557-73. http://www.saskiasassen.com/pdfs/publications/the-global-citybrown.pdf.

Scipioni, A.-MaZzi, A.-Zuliani, F.-Mason, M. (2008): The ISO 14031 Standard to Guide the Urban Sustainability Measurement Process: An Italian Experience Journal of Cleaner Production 16 (12): 1247-57. https://doi.org/10.1016/j.jclepro.2007.06.013.

Soma, K.-Dijkshoorn-Dekker, M. W. C.-Polman, N. B. P. (2018): Stakeholder Contributions through Transitions towards Urban Sustainability Sustainable Cities and Society 37: 438-50. https://doi.org/10.1016/j.scs.2017.10.003.

SzEMERE, S.-RAB, J. (2016): Az okos város fejlesztési modellről Információs Társadalom 16 (3): $146-56$.

TAppert, S.-KLÖTI, T.-Drilling, M. (2018): Contested Urban Green Spaces in the Compact City: The (Re-)Negotiation of Urban Gardening in Swiss Cities Landscape and Urban Planning 170: 69-78. https://doi.org/10.1016/j.landurbplan.2017.08.016.

Trindade, E. P.-Hinnig, M. P. F.-DA Costa, E. M.-Marques, J. S.-Bastos, R. C.YigitCANLAR, T. (2017): Sustainable Development of Smart Cities: A Systematic Review of the Literature Journal of Open Innovation: Technology, Market, and Complexity 3 (11). https://doi.org/10.1186/s40852-017-0063-2.

Tsuboi, S.-IKaruga, S.-Kobayashi, T. (2016): Method for the Proposal and Evaluation of Urban Structures for Compact Cities Using an Expert System Frontiers of Architectural Research 5 (4): 403-11. https:/ / doi.org/10.1016/j.foar.2016.09.003.

VERREST, H.-PFEFFER, V. (2018): the Urbanism in Smart Urbanism: Distilling Relevant Dimensions for a Elaborating Comprehensive Analysis of Smart City Approaches Information Communication and Society 4462: 1-15. https://doi.org/10.1080/1369118X.2018.1424921.

Yamagata, Y.-SEYA, H. (2013): Simulating a Future Smart City: An Integrated Land UseEnergy Model Applied Energy 112: 1466-74.

https://doi.org/10.1016/j.apenergy.2013.01.061. 